\title{
NEGOTIATING MOTHERHOOD IN CONSTRAINING SPACE IN EMMA DONOGHUE'S ROOM
}

\author{
Putti Aisyah, Hujuala Rika Ayu \\ Universitas Negeri Surabaya \\ puttialif@mhs.unesa.ac.id,hujualarika@unesa.ac.id
}

\section{Abstract}

This study sheds light on how Ma, the female character in Emma Donoghue's Room negotiates her roles as a mother of a five-years-old Jack while living inside a constraining room built by Nick, her kidnapper. It particularly focuses on how $\mathrm{Ma}$ attempts to re-define her motherhood within built and discursive spaces that Nick constructs. The study employs the concepts of Sarah Ruddick on maternal thinking and Marsha Marotta's Mother Space. Marrota delineates two aspects contributing to shape mother's subjectivity; built spaces and discursive spaces. In the case of Ma, built space is the $11 \times 11 \mathrm{~m}$ room representing Nick's authority. Nick also partly constructs the discursive space within the room. The finding shows that Ma is able to create her own discursive space as her effort of conforming her motherhood, within the constraining built space. Ma successfully performs her sense of motherhood - such as providing him physical needs like nutritious food and nurturing his cognitive development.

Keywords: Motherhood, motherspace, built space, discursive space

\section{INTRODUCTION}

This paper examines the efforts of the mother figure, Ma, in Emma Donoghue's Room in performing her motherhood within a confining situation. Nick, the kidnapper, creates the confining situation in the form of a 11x11 room where he uses his power to control Ma and Jack. This paper applies the concepts of Sarah Ruddick on maternal thinking and Marsha Marotta's motherspace. Marotta in MotherSpace: Disciplining through the Material and Discursive (2005) emphasizes the significances of built and discursive spaces in constructing motherhood. This paper particularly sees the interaction of distinguished spaces in Donoghue's Room in shaping the subjectivity of Ma.

Emma Donoghue's Room tells about a girl being kidnapped and locked in a 11x11 m room. Nick, the male character in the novel kidnapped Ma when she was 19 years old. During her captivity, she gave birth to a boy named Jack. Together they live in this small room for seven years. The room is soundproof and no insulation at all. The kidnapper 
supports them with enough electricity, water, and food. There is only a glass window on the ceiling of their room and all daily life equipment such as bed, bathtub, wardrobe, television, and kitchen all in one space. The only connecting door to the outside is fitted with an electronic safety lock with a secret code, which is only known to the kidnapper.

Being a mother is one of the most powerful acts that a woman can perform. McDaniels states that - when someone chooses a position as a mother, she chooses to give a large part of her life to the process of producing, guiding, and managing the lives of others (2004). However, in the case of Ma, being a mother is a forced one. It is not a choice. Being a forced mother within the constraining situation, she in fact, is challenged to show the behavior of compassion and mutual care for her child. This paper firstly unravels the geography of the room as the constraining space then sees how Ma performs her motherhood within that limiting space.

\section{THEORETICAL FRAMEWORK}

This study specifically applies Marsha Marotta's theory of MotherSpace and Iris Young in Motherhood and Space: Configurations of the maternal through politics, home, and the bod (2005). Motherhood is the state of being a mother based on the lexicon. The author describes motherhood as a state when a woman gives birth to a child and then her world changes. Marotta emphasizes that motherhood is a social construction, calling attention to the role it plays in political and social control (p. 17). As a social construction, it is not nature that determines how mothers should be at any particular point in time but rather ideology and cultural forces. Women have babies and care for those babies. Motherhood and motherSpace are tied to the historical moments in ways that reflect power relations at that moment.

Marotta describes MotherSpace as a way of making power relations within and through the function of being a mother. This becomes clear when the focus is on the practices of mothers. Marotta then adds the meaning of practices from Foucault' quotation "practices may be understood as places where what is said and what is done, rules imposed and reasons were given, the planned and the taken for granted meet and interconnect" (Burchell, Gordon, \& Miller, 1991, p. 75).

Combining her understanding and Foucault's statement above, it can be concluded that the everyday habits and activities of individuals include disciplinary practices which help create environments and behaviors, which contribute to the construction of particular kinds of individuals who tend to follow the social order and rules, tend to live their lives according to the prevailing ideology of the time. Foucault explains, for example, that society tends to make rules about what is right and what is wrong, and also what are the punishments if someone disobeys the rules. This order and rules have been made to maintain what society sees as the balance among them.

Furthermore, the discourse that supports the rules and orders within society must be taught to the young generation which becomes the task of every parent. The main task of a mother specifically. Then, as a conclusion, Marotta describes this task has become the 
space that limits the movements and behavior of mothers as this task is required to complete the function control of mothers. Marotta states that through the variables of territory, communication, and speed, mothers are encouraged to feel powerless to escape MotherSpace (p. 19). Like the panopticon, which is based on the normalizing gaze that establishes the visibility of power, MotherSpace is linked with seeing and being seen. For mothers, material space is arranged in such a way that their presence or absence is immediately visible. Discursive space is organized so that if children are unruly or engage in risky behaviors, mothers are criticized for being absent and blamed if anything goes wrong. Marotta sees mothers as objects rather than subjects (p. 20). This is especially can be found in a space where neighbors do not know one another so that mothers feel isolated from others.

Furthermore, in Maternal Thinking: toward a Politics of Peace (2005), Ruddick emphasizes the importance of maternal practice as part of performing motherhood. She defines maternal pratice as "a response to the reality of a biological child in a particular social word" (p. 17). In this context, motherhood is directed toward the fulfilment of children needs within certain social cluster. Maternal practice is therefore characterized by three demands: preservation, growth, and social acceptance. Being a mother means being committed to fulfill these demands, not only for the child's sake but also for the social groups in which a mother is recognized "whether by force, kinship or choice", through the work of preservative love, care, and training.

The first duty of mothers is to protect, preserve their children and, to keep them safe. Preserving the lives of children is the central constitutive and also the aim of maternal practice. Ruddick also added that to be committed to meet children's demand for preservation does not require enthusiasm or even love; it means seeing vulnerability and responding with caution rather than harassment, ignorance, or running away (p.19).

The second demand of motherhood is to nurture the children's emotional and intellectual growth as Confortini and Ruane (2013) explained below:

To foster growth ... is to sponsor or nurture a child's unfolding, expanding material spirit. Children demand this nurturance because their development is complex, gradual, and subject to distinctive kinds of distortion or inhibition.... Children's emotional, cognitive, sexual, and social development is sufficiently complex to demand nurturance; this demand is an aspect of maternal work ... and it structures maternal thinking (p. 83).

The third demand for maternal practice is training and social acceptability of children where children is formed by a social group where the mothers belong to. Then, the children will be "accepted" as the mothers teach them in "acceptable" ways based on the groups. The acceptance is believed as something unnatural, cannot grow naturally, therefore, children need their mothers to train them. The training methods could be varied, from respectful to abusive, or even mix of some methods (p. 21). 


\section{METHOD}

As a descriptive qualitative research, close reading is particularly used in this research to analyze the novel and answer the questions proposed in the introduction. Reading a novel is important to accomplish the themes of the novel. The data are limited on the mother's parenting style for the development of the son. The next procedure is making an outline of the whole content of the thesis. In the outline, it has been decided what statements of the problem are going to be. The first part of the discussion focuses on elaborating the room as the built space and how the room supports Ma's motherhood. The second part of the discussion emphasizes on the discursive space and how within this limited discursive space Ma's negotiate her efforts.

\section{DISCUSSION}

\section{Room as the Embodiment of Built Space}

Part of this paper focuses on the bodily description of the room. The title of the novel, Room, can be understood as a fixed and concrete place, principally comprising the inside and the outside parts. Referring to the concept of motherspace, room can be categorized into the built or material space that are "bounded and visible" (Marotta, p.15). Marotta uses the word "space" interchangeably to not merely refer to particular location but also "the practices associated with assignments or roles that are carried out there" (p. 16).

Physically, the room where Ma and Jack are being locked is around $11 \times 11 \mathrm{~m}$ for. Together they live in a small room for seven years. The room is soundproof and no insulation at all. The kidnapper supported them with enough electricity, water, and food. There was only a glass window on the ceiling of their room and all daily life support equipment such as bed, bathtub, wardrobe, television, and kitchen all in one space. The only connecting door to the outside was fitted with an electronic safety lock with a secret code, which was only known to the kidnapper.

Inside the room, Jack is Ma's life. She spends every moment with him, educating him, feeding him, playing with him. She still breastfeeds him too, which is normal within the Room because in the room they only belong to each other. No rules or categories to be fitted as the right or wrong one. Unlike Jack, Ma wants to return to the outside world. Jack does not know anything besides the room. Jack divides the world into two areas of realms. There is Room, as Jack calls it because he can name things inside the room into characters as he please and his mother teaches him how to. The second area is Outer Space. For Jack, Room is a place of such warmth, fun, intimacy, and routine. For Ma, it's a very different story. Seven years earlier she was on her way to her college's library when she met a bad man who kidnapped her as she explained how Old Nick kidnapped her.

The first one is to protect and preserve their children means to fulfill their body needs to keep on living. A mother has to provide milk and notorious food for her child. Keeping a child healthy is not only giving food but also how to make their body fit as well through exercise. 
I can smell Ma beside me, I've got the best nose in the family. "Oh, I forgot to have some when I woke up."

"That's OK. Maybe we could skip it once in a while, now you're five?"

"No way Jose."

So she lies down on the white of Duvet and me too and I have lots. (8)

Jack is still breastfeeding even though he is 5 years old. The quotes above show when Jack woke up he was laying next to Ma and ask for the milk. Normally, the breastfeeding will stop when the child is 2 years old. However, in Ma's situation, she only wants the best nutrition for her son, Jack so that he will not get sick easily since they were being captive and she is sure that Old Nick will not bring Jack to go see doctor is he is sick. Therefore, the best she can do is giving him the best medicine and nutrition, her breast milk. The breastfeeding has made Jack healthy and that's why Ma still continue giving him even after they have escaped the room.

The second demand of motherhood is to nurture the children's emotional and intellectual growth. As mothers, they are responsible to teach their children not only how to speak but also how to solve the problem and support them with basic knowledge. Usually, children can start attending school when they are around 3 or 4 years. However, in Ma's case, she is the only one to teach Jack all of that since she is being kidnapped and locked in a small room. Despite her captivity in Room. She civilizes and humanizes Jack. She passes on her cultural knowledge to him, from religion to tooth-brushing to rules. Indeed, throughout their five years of captivity, Ma commits to the preservation, nurturance, and training of Jack.

As a mother, Ma has given her best to her son, Jack. She has kept jack safe from Old Nick for 5 years. Ma teaches Jack how to read, write, play, and how to imagine through the storybooks he read. Ma scheduled everything for Jack's training in proper time: storytelling, exercises, eating, playing, bath, etc. She instructs him like an instructor, teach him like a teacher, and guide him like a friend. Jack is taught through demonstrations, illustrations, and narration of multiple stories. Therefore, Ma already gives Jack what he needs mentally and cognitively. It means Ma has fulfilled the second demand of what is called the good motherhood

The third demand is social acceptability. This skill of acceptability cannot naturally develop in social context but it has to be trained (Ruddick, p.21). It has to be trained since it will be the assignment to see a mother's active aims to make her children 'acceptable'. Every mother's training strategy might be different such as persuasive, manipulative, educative, abusive, seductive, or respectful and are typically a mix of most of these. However, once a woman become successful in being a good mother to her children can be seen also from this social acceptability demand.

The social acceptability can be seen through the good bonding between Ma and Jack. They both accept their roles and existence towards each other. Ma has taught Jack how to react and respond to her as his mother. This is the example for basic socialization, interact with other people. And not only with Ma, Jack also has developed interaction with Old 
Nick. Jack always thinks that Old Nick is the bad guy. They don't really talk much about Old Nick since Ma wants to protect Jack from him.

"Get away, get away from him!"

"I can be quiet," she says, she's nearly whispering. I hear her breath all scratchy. "You know how quiet I can be, so long as you leave him alone. It's all I've ever asked." (p.27)

\section{Ma's Negotiation of Motherhood in the Constraining Room}

Ma's psychological trauma that pushes her to the point of emotional breakdown, but rather the trauma induced by the interviewer's violent attempts to shape, control, and manipulate Ma's narrative (Ruddick, 11). Ma starts to control her son in almost everything. She gives schedules and order to Jack for daily activities, including in how to act towards Old Nick. Normative motherhood assumes and dictates an asymmetrical relationship between mother and child: a mother is for the child, not the child for the mother (Ruddick, p.11). But with Ma and Jack, their relationship is truly reciprocal. Ma needs Jack as much as Jack needs Ma. But because this reciprocity violates the roles and rules of normative motherhood based on society standard, Ma is labeled as a bad mother in her decision to keep Jack with her in captivity.

However, despite of her psychological trauma, Ma sees Jack as her salvation. She is willing to put Jack's need of mother than her suffering. For Ma, becoming and being a mother is indeed the best thing because it is precisely through her maternal practice and the reciprocity of her close relationship with Jack that she acquires an authentic selfhood. And because her identity as a mother is self-created and sustained by reciprocal motherchild love, Ma establishes resistance and achieves redemption in motherhood. In its portrayal of motherhood as both resistant and redemptive, Room offers a necessary challenge and corrective to normative motherhood. It conveys how mothers may be empowered through maternal authenticity and mother-child reciprocity.

Marotta states that through the variables of territory, communication, and speed, mothers are encouraged to feel powerless to escape MotherSpace (p. 19). Despite being strong in front of Jack as his mother, Ma also feel powerless towards Old Nick. She really depends on Nick for their daily needs, and also she cannot win Old Nick physically. For mothers, material space is arranged in such a way that their presence or absence is immediately visible. This situation has matched with the way Ma taking care of Jack inside the room where she conducts normative motherhood towards Jack. She take care everything related to Jack's need, activities, and his growth. Being locked in the room doesn't give her much opportunity to give Jack better chances in his needs. Despite being bitter and being angry to Jack, Ma tries her best to be a good mother to him because she loves Jack very much.

Being a mother in a society mean women has to fulfill its standard. For women, this standard can be seen as the space that limits their way to do their own motherhood to their children. As Marotta argues, the society persuades mothers to engage in certain practices that reflect choices that put the needs of others before their own. When we link practices 
with the construction of subjectivities, we can begin to understand why, beyond violence or the coercion of force or economics, mothers make 'choices' that reduce their income, benefits, time to develop themselves, and so on. Society tends to make rules about what is right and what is wrong, and also what are the punishments if someone disobeys the rules. The punishment may come in social judgment and people will label a woman as bad mother if she does not fulfill their standard. In Ma's case she was being judged for giving Jack breast milk even though Jack is already 5 years old. According to society rules, mother should stop breast feeding their children at the age of two. However, in Ma's situation, she need to keep Jack healthy and all she knows best is her breast milk. She surely know if Jack get sick, Old Nick will never want to bring Jack to go to see doctor.

Society wants to educate Ma about what is right and what is wrong about her way of motherhood and this has made her depressed. The main task of motherhood is always given to the mother since we live in patriarchy society. In the patriarchal society as stated by Young, a woman serves as the construction material and as the place within which man dwell. Woman serves as the material envelope and container of man existence. Man seeks nostalgically to return to home by making buildings and putting things in them that will substitute for that original home. Therefore, the task for nurturing the children will always be the mother's side. That's why the terms will always be motherhood instead of fatherhood. This pressure from society has once again creates space to limit Ma's motherhood towards Jack. The rules and judgment from society limit the movements and behavior of mothers as this task is required to complete the function control of mothers. What become the contrary is the rules in society often changes between time to time. For example about formula milk and breast milk, during 1980-2000, society tend to campaign for formula milk for the babies born on that era. Nowadays, in millennial time, the campaign of giving breast milk feeding until the babies reach 2 years old is a mandatory. Nothing is permanent about society rules and assignment since the society itself also develops between time to time. There will be new rules, new standard, and new assignments for parents. Therefore nothing can be used permanently or correctly as standard to judge how a woman is a good mother or bad mother.

\section{CONCLUSION}

This study concludes that Ma has accomplished three demands of motherhood inside the room. The first one is to take care of Jack growth by giving him physical need like nutritious food. And the second one is the cognitive development of a child where Ma has taught Jack to read, to think, and to be able to imagine a story of his own through the story-telling activity. The third demand is accomplished later after they got out from the room. At the end of the story, Ma and Jack can live in their own home and they both seem has adapted to society and continue their live together.

Ma's motherhood has been limited by space both inside and outside the room. Inside the room, the space is the room itself, where she has limited access to knowledge about motherhood and she only takes care of Jack based on what she knows. Once Ma and Jack 
escaped from the room, Ma once again has faced the space created by society. The space crated is the rules and assignment for women to be considered as good or bad mother. Society wants to know how Ma take care Jack alone inside the room and they want to make sure that Ma has fulfilled their standard to make sure Ma has the label as good mother according to their standard.

\section{REFERENCES}

Confortini, C. C., \& Ruane, A. E. (2013). Sara Ruddick's Maternal Thinking as weaving epistemology for justpeace. Journal of International Political Theory, 10(1), 70-93.

Foucalt, Michel. (1991). Questions of Method. In Burchell, G., Gordon, C., \& Miller, P. (eds). The Foucalt effect: Studies in Governmentality with two lectures by and an interview with Michel Foucault (pp.75-86). Chicago: The University of Chicago.

Hardy, Sarah., \& Wiedmer, C. (2005). Motherhood and Space (1st ed.). New York: Palgrave Macmillan.

Lefebvre, Henry. (1991). The Production of Space. Donald Nicholson-Smith (transl). Oxford and Cambridge: Blackwell.

Marrota, Marsha. (2005). Motherspace: Disciplining through the Material and Discursive. In Hardy, Sarah, \& Weidmer, Caroline (eds), Motherhood and Space: Configurations of the maternal through politics, home and the body (pp.15-33). New York: Palgrave Macmillan.

Massey, Doreen. (1994). Space, Place and Gender. Minneapolis: University of Minnesota.

Mcdaniels, P. W. (2004). Mothering modes: analyzing mother roles in novels by twentiethcentury United States women writers. (Unpublished doctoral dissertation). Louisiana State University, Louisiana, United States Of America.

O'reilly, A. (2010). “ All Those Years , I KeptHim Safe ” Maternal Practice as Redemption and Resistance in Emma Donoghue's Room. Journal of the Motherhood Initiative for Research and Community Involvement, 8, 89-98.

Parker, Rozsika. (1997). The Production and Purposes of Maternal Ambivalence in Hollway, Wendy \& Featherstone, Brid (eds). Mothering and Ambivalence (pp.17-36). London and New York: Routledge.

Rich, Adrienne. (1995). Of Woman Born: Motherhood as Experience and Institution. New York \& London: W.W. Norton \& Company.

Ruddick, S. (1995). Maternal Thinking Toward a Politics of Peace. Boston: Beacon Press books. Ue, Tom. (2012). An Extraordinary Act of Motherhood: a Conversation with Emma Donoghue. Journal of Gender Studies, vol 21, 1, pp.101-106.

Young, Iris Marrion. (2005). House and Home: Feminist Variatins on a Theme in Hardy, Sarah \& Wiedmer, Caroline (eds). Motherhood and Space: Configurations of the maternal through politics, home and the body (pp. 115-147). New York: Palgrave Macmillan. 